\title{
FAKTOR-FAKTOR YANG BERHUBUNGAN DENGAN KEJADIAN KOMPLIKASI PERSALINAN DI WILAYAH KERJA PUSKESMAS TANJUNG BINTANG KABUPATEN LAMPUNG SELATAN
}

\author{
Mutia Erlina Arisandi ${ }^{1}$, Anita ${ }^{2}$, Zaenal Abidin ${ }^{3}$ \\ ${ }^{1}$ Puskesmas Tanjung Bintang Kabupaten Lampung Selatan \\ ${ }^{2}$ Jurusan Keperawatan Poltekkes Tanjungkarang \\ ${ }^{3}$ Fakultas Kesehatan Masyarakat, Universitas Malahayati Bandar Lampung \\ Email: arisandimutia000@gmail.com
}

\begin{abstract}
The Related Factors to Delivery Complication Cases in Tanjung Bintang Public Health Center (PHC) Working Areas, South Lampung District . Delivery complication is a condition that can harm health of mother and her infant in delivery, and it is influenced by intermediate determinants. The objective of this research was to find out the factors related to delivery complication cases in Tanjung Bintang PHC working areas, South Lampung District. This was a quantitative observational research with case control design. Population containing of 221 case population and 1429 control population. 208 total samples were taken by using circular systematic sampling and divided into case and control with ratio of 1:1. Research variables were delivery complication, age, parity, pregnancy interval, nutrition status, pregnancy complication history, and antenatal care use. Data were analyzed by using univariate, bivariate and multivariate (Chi Square test and Multiple Logistic Regression at $\alpha=5 \%$ ). The analysis results are the following: (1) there were $13.0 \%$ respondents were in risky ages, $38.5 \%$ respondents were in risky parities, $63.9 \%$ respondents had risky pregnancy interval, $17.8 \%$ respondents had poor nutrition status, $21.6 \%$ respondents experienced pregnancy complication, and $33.7 \%$ respondents did not use antenatal care; (2) the variables that simultaneously related to delivery complication, they were pregnancy interval $(\mathrm{p}=0.004, \mathrm{OR}=2.6)$, nutrition status $(\mathrm{p}=0.000, \mathrm{OR}=4.9)$, pregnancy complication history $(\mathrm{p}=0.003, \mathrm{OR}=3.1)$, and using antenatal care service $(\mathrm{p}=0.009, \mathrm{OR}=2.3)$. The most dominant variable was nutrition status $(\mathrm{OR}=4.9)$.
\end{abstract}

Keywords: Delivery Complication, Pregnancy Complication, Using Antenatal Care

\begin{abstract}
Abstrak: Faktor-Faktor yang Berhubungan dengan Kejadian Komplikasi Persalinan di Wilayah Kerja Puskesmas Tanjung Bintang Kabupaten Lampung Selatan. Komplikasi persalinan adalah keadaan yang dapat membahayakan kesehatan \& keselamatan ibu \& bayinya dalam persalinan, yang dipengaruhi oleh determinan antara. Tujuan penelitian diketahuinya faktorfaktor yang berhubungan dengan kejadian komplikasi persalinan di wilayah kerja Puskesmas Tanjung Bintang Kabupaten Lampung Selatan. Jenis penelitian ini kuantitatif analitik observasional dengan rancangan Case Control. Populasi kasus 221 dan populasi kontrol 1429. Sampel 208 terdiri dari sampel kasus \& kontrol dengan perbandingan $1: 1$. Variabel penelitian yaitu kejadian komplikasi persalinan, umur, paritas, jarak kelahiran, status gizi, riwayat komplikasi kehamilan, pemanfaatan ANC. Analisis data : univariat, bivariat, dan multivariat dengan uji $C h i$ Square dan regresi logistik ganda, $\alpha=5 \%$. Hasil penelitian : 1) terdapat 13,0\% umur berisiko, $38,5 \%$ paritas berisiko, 63,9\% jarak kelahiran berisiko, 17,8\% status gizi tidak baik, 21,6\% ada riwayat komplikasi kehamilan, 33,7\% tidak memanfaatkan ANC. 2) variabel yang secara bersamasama berhubungan dengan komplikasi persalinan, yaitu status gizi $(p=0,000, \mathrm{OR}=4,9)$, riwayat komplikasi kehamilan $(p=0,003$, OR=3,1), jarak kelahiran $(p=0,004, \mathrm{OR}=2,6)$, dan pemanfaatan ANC $(p=0,009, \mathrm{OR}=2,3)$. Variabel yang paling dominan adalah status gizi $(\mathrm{OR}=4,9)$.
\end{abstract}

Kata kunci: Komplikasi Persalinan, Komplikasi Kehamilan, Pemanfaatan ANC

Kematian ibu hampir $90 \%$ terjadi pada saat persalinan dan segera setelah persalinan. Penyebab langsung kematian ibu antara lain komplikasi kehamilan dan persalinan, dimana $50 \%$ komplikasi kehamilan dan persalinan yang menjadi penyebab langsung kematian ibu. (Depkes, 2009., Kemenkes RI, 2013).

Berdasarkan MDGs 2000, Indonesia berkomitmen bahwa pada tahun 2015 untuk menurunkan AKI dari 408/100.000 KH menjadi 102/100.000 KH, AKB dari 68/1.000 KH 
menjadi 23/1.000 KH, dan AKBa dari 97/1.000 KH menjadi 32/1.000 KH. (Depkes, 2009)

Namun upaya-upaya yang dilakukan untuk mewujudkan komitmen tersebut, sampai saat ini belum mendapatkan hasil yang memuaskan. AKI dan AKB di Indonesia masih tinggi dibandingkan dengan negara ASEAN lainnya. Data Survei Demografi Kesehatan Indonesia (SDKI) 2007 diketahui bahwa, AKI di Indonesia adalah 228/100.000 KH dan AKB 34/1.000 KH. Hasil SDKI 2012 AKI justru melonjak tajam menjadi 359/100.000 KH, dan AKB turun meskipun penurunannya hanya dua basis poin menjadi 32/1.000 KH (Kemenkes RI, 2013).

Pada tahun 2012 di Provinsi Lampung terjadi 178 kasus kematian ibu. Penyebab kematian ibu sebanyak $57,86 \%$ karena komplikasi persalinan yaitu eklampsi (59 kasus), perdarahan (40 kasus), dan infeksi (4 kasus). Tahun 2013 di Provinsi Lampung masih terdapat 158 kasus kematian ibu. Penyebab kematian ibu sebanyak 65,19\% karena komplikasi persalinan yaitu perdarahan (47 kasus), eklampsi (46 kasus), infeksi (9 kasus), dan satu kasus partus lama (Dinkes Prov.Lampung, 2012-2013).

Kabupaten Lampung Selatan merupakan kabupaten dengan kasus kematian ibu nomor tiga pada tahun 2012. Tahun 2013 terdapat 7 kasus kematian ibu, dan merupakan kabupaten dengan kasus kematian Perinatal nomor empat, kematian Neonatal nomor lima, dan kabupaten dengan kasus kematian bayi nomor tiga di Propinsi Lampung. (Dinkes Prov.Lampung, 2012-2013)

Tahun 2012-2015 di wilayah kerja Puskesmas Tanjung Bintang terdapat kasus kematian ibu dengan kecenderungan meningkat, dan terdapat kasus kematian bayi dengan kecenderungan fluktuatif. Pada 2015 terdapat persalinan dengan komplikasi sebanyak $13,65 \%$, dan menyebabkan tiga kematian ibu dan enam kematian bayi (Profil Puskesmas Tanjung Bintang, 2015).

Kehamilan dan persalinan merupakan proses reproduksi yang normal, akan tetapi tetap mempunyai risiko untuk terjadinya komplikasi. Deteksi dini faktor risiko dan komplikasi kehamilan dan persalinan, serta penanganan komplikasi yang adekuat sedini mungkin merupakan salah satu upaya mencegah kesakitan dan kematian ibu dan bayi. (Manuaba, 2012)

Komplikasi kehamilan dan persalinan yang menyebabkan kematian dan kesakitan ibu dan janin dipengaruhi oleh determinan antara dan determinan jauh. Determinan antara dipengaruhi oleh determinan jauh yang digolongkan sebagai komponen sosioekonomi dan budaya (Prawirohardjo, 2014).

\section{METODE PENELITIAN}

Jenis penelitian ini adalah kuantitatif analitik observasional dengan rancangan Case Control. Populasi setelah restriksi sebanyak 1650 ibu bersalin Januari s/d Desember 2015, yaitu populasi kasus 221 dan populasi kontrol 1429. Sampel 208 terdiri dari sampel kasus \& kontrol dengan perbandingan 1:1, yang ditetapkan dari hasil perhitungan rumus sampel Case Control pengujian hipotesis terhadap OR dengan $\alpha=5 \%$, $\beta=20 \%$, dan diambil dengan Circular Systematic Sampling.

Variabel penelitian yaitu kejadian komplikasi persalinan, umur, paritas, jarak kelahiran, status gizi, riwayat komplikasi kehamilan, pemanfaatan ANC.

Instrumen penelitian ini adalah formulir observasi dan kuisioner. Pengolahan data terdiri dari pemeriksaan dan pembersihan data, pemberian kode, dan pemrosesan. Analisis data terdiri dari univariat, bivariat, dan multivariat dengan uji Chi Square dan Regresi Logistik Ganda, $\alpha=5 \%$.

\section{HASIL}

\section{A. ANALISIS UNIVARIAT}

Berdasarkan pengumpulan data dan pengolahan data diperoleh deskripsi tiap-tiap variabel penelitian, sebagaimana tampak pada tabel 1. Diketahui bahwa, di wilayah kerja Puskesmas Tanjung Bintang tahun 2015 terdapat sebagian kecil $(13,0 \%)$ ibu bersalin dengan kategori umur berisiko. Pada kelompok kasus, terdapat sebagian kecil $(18,3 \%)$ ibu bersalin kategori umur berisiko dan lebih sedikit dibandingkan ibu bersalin kategori umur tidak berisiko $(81,7 \%)$. 
206 Jurnal Kesehatan, Volume VII, Nomor 2, Agustus 2016, hlm 204-210

Tabel 1. Distribusi Statistik Variabel Penelitian

\begin{tabular}{|c|c|c|c|c|c|c|c|}
\hline \multirow{2}{*}{\multicolumn{2}{|c|}{ Variabel }} & \multicolumn{2}{|c|}{ Kasus } & \multicolumn{2}{|c|}{ Kontrol } & \multicolumn{2}{|c|}{ Jumlah } \\
\hline & & $\mathbf{n}$ & $\%$ & $\mathbf{n}$ & $\%$ & $\bar{n}$ & $\%$ \\
\hline \multirow[t]{3}{*}{ 1. Umur Ibu } & Berisiko & 19 & 18,3 & 8 & 7,7 & 27 & 13,0 \\
\hline & Tidak Berisiko & 85 & 81,7 & 96 & 92,3 & 181 & 87,0 \\
\hline & Jumlah & 104 & 100 & 104 & 100 & 208 & 100 \\
\hline \multirow{3}{*}{ 2. Paritas } & Berisiko & 48 & 46,2 & 32 & 30,8 & 80 & 38,5 \\
\hline & Tidak Berisiko & 56 & 53,8 & 72 & 69,2 & 128 & 61,5 \\
\hline & Jumlah & 104 & 100 & 104 & 100 & 208 & 100 \\
\hline \multirow[t]{3}{*}{ 3. Jarak Kelahiran } & Berisiko & 74 & 71,2 & 59 & 56,7 & 133 & 63,9 \\
\hline & Tidak Berisiko & 30 & 28,8 & 45 & 43,3 & 75 & 36,1 \\
\hline & Jumlah & 104 & 100 & 104 & 100 & 208 & 100 \\
\hline \multirow[t]{3}{*}{ 4. Status Gizi } & Tidak Baik & 28 & 26,9 & 9 & 8,7 & 37 & 17,8 \\
\hline & Baik & 76 & 73,1 & 95 & 91,3 & 171 & 82,2 \\
\hline & Jumlah & 104 & 100 & 104 & 100 & 208 & 100 \\
\hline \multirow[b]{3}{*}{ Kehamilan } & Ya T & 30 & 28,8 & 15 & 14,4 & 45 & 21,6 \\
\hline & Tidak Te & 74 & 71,2 & 89 & 85,6 & 163 & 78,4 \\
\hline & Jumlah & 104 & 100 & 104 & 100 & 208 & 100 \\
\hline \multirow{3}{*}{$\begin{array}{l}\text { 6. Pemanfaatan } \\
\text { ANC }\end{array}$} & Tdk Men & 43 & 41,3 & 27 & 26,0 & 70 & 33,7 \\
\hline & Memanfa & 61 & 58,7 & 77 & 74,0 & 138 & 66,3 \\
\hline & Jumlah & 104 & 100 & 104 & 100 & 208 & 100 \\
\hline
\end{tabular}

Terdapat lebih dari seperempat $(38,5 \%)$ ibu bersalin dengan kategori paritas berisiko. Pada kelompok kasus, terdapat kurang dari separuh $(46,2 \%)$ ibu bersalin dengan kategori paritas berisiko dan lebih sedikit dibandingkan ibu bersalin dengan kategori paritas tidak berisiko $(53,8 \%)$.

Terdapat lebih dari separuh $(63,9 \%)$ ibu bersalin dengan kategori jarak kelahiran berisiko. Pada kelompok kasus, terdapat hampir mencapai tiga perempat $(71,2 \%)$ ibu bersalin dengan kategori jarak kelahiran berisiko dan lebih banyak dibandingkan ibu bersalin dengan kategori jarak kelahiran tidak berisiko $(28,8 \%)$.

Terdapat sebagian kecil $(17,8 \%)$ ibu bersalin dengan kategori status gizi tidak baik. Pada kelompok kasus, lebih dari seperempat $(26,9 \%)$ ibu bersalin dengan kategori status gizi tidak baik dan lebih sedikit dibandingkan ibu bersalin dengan kategori status gizi baik $(73,1 \%)$.

Terdapat kurang dari seperempat $(21,6 \%)$ ibu bersalin yang mempunyai riwayat komplikasi kehamilan. Pada kelompok kasus, terdapat lebih dari seperempat $(28,8 \%)$ ibu bersalin dengan kategori ada riwayat komplikasi kehamilan dan lebih sedikit dibandingkan ibu bersalin dengan kategori tidak ada riwayat komplikasi kehamilan $(71,2 \%)$.

Terdapat lebih dari seperempat $(33,7 \%)$ ibu bersalin dengan kategori tidak memanfaatkan ANC. Pada kelompok kasus, terdapat kurang dari separuh $(41,3 \%)$ ibu bersalin dengan kategori tidak memanfaatkan ANC dan lebih sedikit dibandingkan ibu bersalin dengan kategori memanfaatkan ANC $(58,7 \%)$.

\section{B. ANALISIS BIVARIAT}

Berdasarkan tabel 2 diketahui bahwa, di wilayah kerja Puskesmas Tanjung Bintang tahun 2015 terdapat hasil uji statistik antara umur ibu bersalin dengan kejadian komplikasi persalinan diperoleh nilai $\mathrm{p}=0,039$ lebih kecil dari $\alpha=0,05$ yang artinya ada hubungan bermakna antara umur ibu bersalin dengan kejadian komplikasi persalinan. Hasil uji statistik juga diperoleh $\mathrm{OR}=2,7$ yang artinya umur berisiko merupakan risiko 2,7 kali untuk mengalami komplikasi persalinan dibandingkan dengan umur tidak berisiko.

Hasil uji statistik antara paritas dengan kejadian komplikasi persalinan diperoleh nilai $p=0,033$ lebih kecil dari $\alpha=0,05$ yang artinya ada hubungan yang bermakna antara paritas dengan kejadian komplikasi persalinan. Hasil uji statistik juga diperoleh $\mathrm{OR}=1,9$ yang artinya paritas berisiko merupakan risiko 1,9 kali untuk mengalami komplikasi persalinan dibandingkan dengan paritas tidak berisiko. 
Tabel 2. Hubungan Masing-masing Variabel Penelitian dengan Kejadian Komplikasi Persalinan

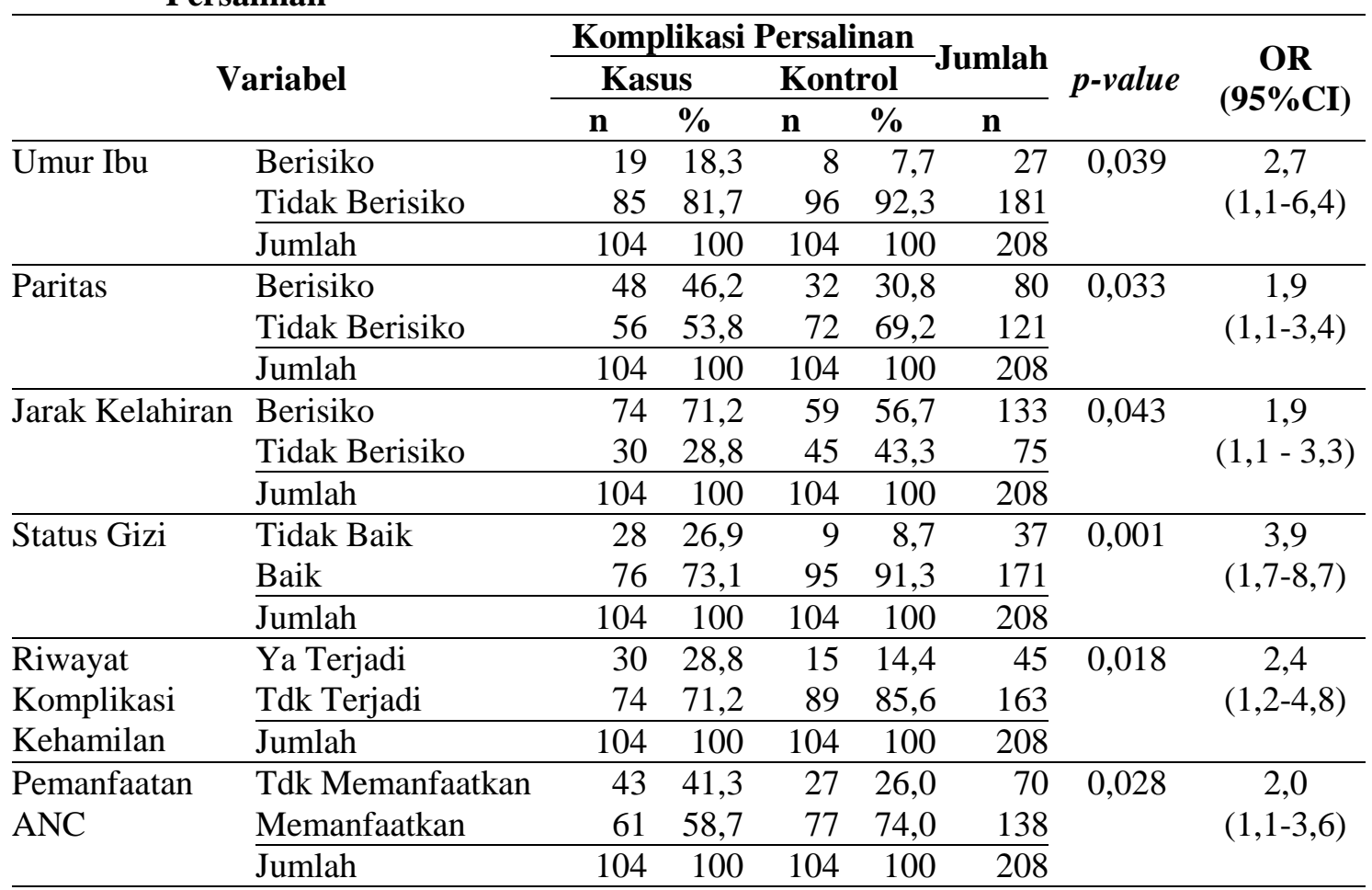

Hasil uji statistik antara jarak kelahiran dengan kejadian komplikasi persalinan diperoleh nilai $\mathrm{p}=0,043$ lebih kecil dari $\alpha=0,05$ yang artinya ada hubungan bermakna antara jarak kelahiran dengan kejadian komplikasi persalinan. Hasil uji statistik juga diperoleh $\mathrm{OR}=1,9$ yang artinya jarak kelahiran berisiko merupakan risiko 1,9 kali untuk mengalami komplikasi persalinan dibandingkan dengan jarak kelahiran yang tidak berisiko.

Hasil uji statistik antara status gizi ibu bersalin dengan kejadian komplikasi persalinan diperoleh nilai $p=0,001$ lebih kecil dari $\alpha=0,05$ yang artinya ada hubungan bermakna antara status gizi ibu bersalin dengan kejadian komplikasi persalinan. Hasil uji statistik juga diperoleh $\mathrm{OR}=3,9$ yang artinya status gizi tidak baik merupakan risiko 3,9 kali untuk mengalami komplikasi persalinan dibandingkan dengan status gizi baik.

Hasil uji statistik antara riwayat komplikasi kehamilan dengan kejadian komplikasi persalinan diperoleh nilai $p=0,018$ lebih kecil dari $\alpha=0,05$ yang artinya ada hubungan bermakna antara riwayat komplikasi kehamilan dengan kejadian komplikasi persalinan. Hasil uji statistik juga diperoleh $\mathrm{OR}=2,4$ yang artinya riwayat komplikasi kehamilan merupakan risiko 2,4 kali untuk mengalami komplikasi persalinan dibandingkan dengan riwayat komplikasi kehamilan yang tidak ada.
Hasil uji statistik antara pemanfaatan ANC dengan kejadian komplikasi persalinan diperoleh nilai $\mathrm{p}=0,028$ lebih kecil dari $\alpha=0,05$ yang ada hubungan bermakna antara pemanfaatan ANC dengan kejadian komplikasi persalinan. Hasil uji statistik juga diperoleh $\mathrm{OR}=2,0$ yang artinya tidak memanfaatkan ANC merupakan risiko 2,0 kali untuk mengalami komplikasi persalinan dibandingkan dengan memanfaatkan ANC.

\section{ANALISIS MULTIVARIAT}

Analisis multivariat penelitian ini bertujuan diketahuinya variabel-variabel yang secara bersama-sama berhubungan dengan komplikasi persalinan, dan mengetahui variabel yang paling dominan berhubungan dengan komplikasi persalinan. Uji statistik yang digunakan adalah Regresi Logistik Ganda dengan menetapkan $\alpha=5 \%$. Langkah-langkah analisis multivariat pada penelitian ini adalah: analisis bivariat identifikasi kandidat model, analisis multivariat pemilihan model dan uji interaksi, dilanjutkan pembuatan model terbaik.

Berdasarkan pengumpulan data dan pengolahan data penelitian ini diperoleh model terbaik untuk memprediksi faktor-faktor yang berhubungan dengan kejadian komplikasi persalinan, sebagaimana tampak pada tabel 3 berikut ini: 
Tabel 3. Model Prediksi Faktor-faktor yang Berhubungan dengan Komplikasi Persalinan

\begin{tabular}{lccrrr}
\hline & & & & \multicolumn{2}{c}{ 95\% C.I. for $\operatorname{Exp}(\mathbf{B})$} \\
\cline { 5 - 6 } & B & Sig. & $\operatorname{Exp}(\mathbf{B})$ & Lower & Upper \\
\hline Jarak Kelahiran & 0,948 & 0,004 & 2,580 & 1,353 & 4,918 \\
Status Gizi & 1,594 & 0,000 & 4,924 & 2,076 & 11,682 \\
Riwayat Komplikasi Kehamilan & 1,146 & 0,003 & 3,146 & 1,482 & 6,677 \\
Pemanfaatan ANC & 0,848 & 0,009 & 2,334 & 1,237 & 4,406 \\
Constant & $-3,139$ & 0,000 & 0,043 & & \\
\hline
\end{tabular}

Berdasarkan tabel 3 dapat diketahui bahwa, Model/ persamaan Logistik yang mempunyai kemaknaan statistik, adalah:

$$
\begin{aligned}
\mathrm{Z}= & \alpha+\beta 1 \mathrm{X} 1+\beta 2 \mathrm{X} 2+\ldots .+\beta \mathrm{iXi} \\
= & -3,139+1,594 \text { (Status Gizi) }+1,146 \\
& (\text { Riw.Kompl.Kehamilan) }+0,948 \text { (Jarak } \\
& \text { Kelahiran) }+0,848 \text { (Pemanfaatan ANC) }
\end{aligned}
$$

Berdasarkan nilai OR dari variabelvariabel dalam model tersebut dapat diketahui bahwa, Status Gizi $(\mathrm{OR}=4,9)$ adalah variabel yang paling dominan berhubungan dengan komplikasi persalinan di wilayah kerja Puskesmas Tanjung Bintang 2015.

Probabilitas/peluang kejadian komplikasi persalinan pada ibu dengan kondisi: status gizi tidak baik (kode hasil ukur=0), ada riwayat komplikasi kehamilan (kode hasil ukur=0), jarak kelahiran berisiko (kode hasil ukur=0), dan tidak memanfaatkan ANC (kode hasil ukur=0), adalah

$$
\begin{aligned}
P(X) & =\frac{1}{1+e^{-z}} \\
& =\frac{1}{1+e^{-\left(a+\sum \beta_{i} X_{i}\right)}} \\
= & \frac{1}{1+} e^{-[-3,139+1,594(0)+1,146(0)+0,948(0)+0,848(0)]} \\
& =\frac{1}{24,0786} \\
& =0,0415(4,15 \%)
\end{aligned}
$$

Berdasarkan hasil perhitungan tersebut dapat disimpulkan bahwa, peluang kejadian komplikasi persalinan pada ibu dengan kondisi: status gizi tidak baik, ada riwayat komplikasi kehamilan, jarak kelahiran berisiko, dan tidak memanfaatkan ANC adalah sebesar 0,0415 $(4,15 \%)$.

\section{PEMBAHASAN}

Berdasarkan hasil penelitian dapat diketahui model terbaik yang mempunyai kemaknaan statistik untuk memprediksi faktorfaktor yang berhubungan dengan komplikasi persalinan di wilayah kerja Puskesmas Tanjung Bintang 2015. Model tersebut terdiri dari empat variabel tanpa variabel interaksi, yaitu: Status Gizi $(p=0,000, \mathrm{OR}=4,9)$, Riwayat Komplikasi Kehamilan $(p=0,003$, OR=3,1), Jarak Kelahiran $(p=0,004, \quad \mathrm{OR}=2,6)$, dan Pemanfaatan ANC $(p=0,009, \mathrm{OR}=2,3)$, dengan konstanta sebesar 3,139 . Status Gizi $(\mathrm{OR}=4,9)$ adalah variabel yang paling dominan berhubungan dengan komplikasi persalinan.

Hasil penelitian ini sejalan dengan McGarthy \& Maine yang menyebutkan bahwa, komplikasi kehamilan dan persalinan dipengaruhi oleh determinan antara dan determinan jauh. Determinan antara tersebut antara lain status kesehatan (status gizi, riwayat komplikasi kehamilan/ persalinan), status reproduksi (umur ibu, paritas, jarak kelahiran), akses terhadap pelayanan kesehatan, perilaku terhadap pelayanan kesehatan (pemanfaatan ANC) (Prawirohardjo, 2014).

Status gizi ibu hamil sangat mempengaruhi pertumbuhan janin dalam kandungan. Jika status gizi ibu buruk, baik sebelum kehamilan dan selama kehamilan, akan menyebabkan berat badan lahir rendah (BBLR), terhambatnya pertumbuhan otak janin, anemia pada bayi baru lahir, bayi baru lahir mudah terinfeksi, abortus, dan sebagainya (Supariasa, 2002., Almatsier, 2004).

Variabel yang paling dominan berhubungan dengan komplikasi persalinan hasil penelitian ini tidak sama dengan hasil penelitian Amargustini (2010) yang menganalisis data sekunder SDKI 2007, dan hasil penelitian Huda (2005) di Banda Sakti Lhokseumawe. Pada hasil penelitian Amargustini disebutkan bahwa, determinan komplikasi persalinan serta faktor yang paling dominan berhubungan dengan komplikasi persalinan adalah riwayat komplikasi persalinan dahulu $(\mathrm{OR}=5,52)$. Pada hasil penelitian Huda disebutkan bahwa, variabel yang 
paling dominan berhubungan dengan komplikasi persalinan adalah penolong persalinan.

Status gizi ibu memegang peranan yang sangat penting selama proses persalinan berlangsung. Satus gizi ibu bersalin yang tidak baik akan mempengaruhi upaya mengejan pada saat ibu akan melahirkan. Ibu cenderung kurang bertenaga dan mudah lelah, sehingga upaya mengejan ibu untuk melahirkan janin tidak efektif. Dibutuhkan tenaga dan ketahanan fisik ibu dalam proses pengeluaran janin, selain teknik mengejan yang benar.

Bayi di dalam kandungan untuk tumbuh dan berkembang memerlukan asupan gizi yang diperoleh dari ibunya melalui plasenta dan tali pusat. Jika status gizi ibu hamil kurang baik maka asupan gizi untuk janin dalam kandungannya juga kurang sehingga dapat menyebabkan terganggunya pertumbuhan janin dan dapat menyakibatkan terjadinya abortus. Status gizi ibu yang kurang baik juga dapat menyebabkan ibu Kekurangan Energi Kronik (KEK) yang dapat membahayakan kesehatan dan keselamatan ibu selama kehamilan, persalinan, dan nifas. Beberapa hal tersebut diatas yang memungkinkan status gizi ibu menjadi variabel yang paling dominan berhubungan dengan komplikasi persalinan.

Deteksi dini adanya masalah terhadap asupan gizi ibu dan komplikasi kehamilan perlu dilakukan untuk meminimalkan faktor risiko status gizi terhadap komplikasi persalinan. Deteksi dini tersebut dapat dilakukan dengan memanfaatkan pelayanan ANC sesuai standar sehingga adanya tanda-tanda bahaya terkait gizi ibu serta penanganan adekuat sedini mungkin dapat segera dilakukan oleh tenaga kesehatan. Selain hal tersebut, ibu dan keluarganya juga perlu memenuhi kebutuhan gizi ibu selama kehamilan, persalinan, dan nifas, serta merencanakan kehamilan berikutnya yang aman dan sehat bagi ibu dan janinnya.

Kehamilan dan persalinan merupakan proses reproduksi yang normal, tetapi tetap mempunyai risiko untuk terjadinya komplikasi. Perlu pemantauan fisik yang normal yang dialami ibu dan tumbuh kembang janin, serta mendeteksi dan menatalaksana setiap kondisi yang tidak normal. Deteksi dini oleh tenaga kesehatan dan masyarakat tentang adanya faktor risiko, komplikasi dan tanda-tanda bahaya serta penanganan adekuat sedini mungkin, merupakan kunci keberhasilan dalam penurunan angka kematian ibu dan bayi yang dilahirkan.

Hasil perhitungan Model Logistik penelitian ini diketahui bahwa, peluang kejadian komplikasi persalinan pada ibu dengan kondisi semua variabel yang ada pada model dalam kategori tidak baik/berisiko adalah sebesar $0,0415(4,15 \%)$. Oleh sebab itu, diperlukan upaya untuk meningkatkan kondisi ibu agar menjadi baik atau tidak berisiko antara lain : peningkatan status gizi ibu, deteksi dini adanya komplikasi kehamilan dan penatalaksanaan yang adekuat sedini mungkin, meminimalkan jarak kelahiran berisiko, dan memberikan pelayanan ANC yang berkualitas sesuai standar operasional untuk pelyanan ANC.

Masyarakat perlu melakukan berbagai upaya untuk mencegah terjadinya komplikasi persalinan, antara lain: mempersiapkan persalinan yang sehat dan aman bagi ibu dan bayinya dimulai sejak masa kehamilan, dengan cara memenuhi kebutuhan zat gizi ibu selama hamil, bersalin, dan nifas, melakukan perawatan kehamilan, memeriksakan kehamilan ke petugas kesehatan (pemanfaatan pelayanan ANC), dan merencanakan persalinan yang sehat dan aman di fasilitas pelayanan kesehatan. Masyarakat juga perlu merencanakan untuk menjarangkan kehamilan berikutnya pada ibu yang berumur 2035 tahun menggunakan metode kontrasepsi jangka panjang (MKJP), serta mengakhiri kehamilan pada ibu yang berumur $>35$ tahun menggunakan metode kontrasepsi tetap (mantap).

\section{SIMPULAN}

1. Terdapat: $13,0 \%$ ibu bersalin dengan kategori umur berisiko, $38,5 \%$ ibu bersalin dengan kategori paritas berisiko, 63,9\% ibu bersalin dengan kategori jarak kelahiran berisiko, $17,8 \%$ ibu bersalin dengan kategori status gizi tidak baik, $21,6 \%$ ibu bersalin yang mempunyai riwayat komplikasi kehamilan, $33,7 \%$ ibu bersalin dengan kategori tidak memanfaatkan ANC.

2. Tidak ada hubungan antara umur ibu bersalin $(p=0,090)$, antara paritas $(p=0,368)$ dengan kejadian komplikasi persalinan. Ada hubungan yang bermakna antara jarak kelahiran $(p=0,004, \mathrm{OR}=2,6)$, antara status gizi ibu $(p=0,000, \mathrm{OR}=4,9)$, antara riwayat komplikasi kehamilan $(p=0,003, \quad \mathrm{OR}=3,1)$, antara pemanfaatan ANC $(p=0,009, \mathrm{OR}=2,3)$, dengan kejadian komplikasi persalinan.

3. Variabel yang secara bersama-sama berhubungan dengan komplikasi persalinan, yaitu status gizi $(p=0,000, \mathrm{OR}=4,9)$, riwayat komplikasi kehamilan $(p=0,003, \quad \mathrm{OR}=3,1)$, jarak kelahiran $(p=0,004, \quad \mathrm{OR}=2,6)$, dan pemanfaatan ANC $(p=0,009, \quad \mathrm{OR}=2,3)$. 
Variabel yang paling dominan adalah status gizi $(\mathrm{OR}=4,9)$.

\section{SARAN}

Untuk Puskesmas Tanjung Bintang Kab. Lampung Selatan :

1. memberikan pelayanan ANC berkualitas sesuai standar operasional yang ditetapkan (pelayanan "10 T").

2. melakukan penyuluhan tentang determinan komplikasi persalinan dengan penekanan pada penyuluhan gizi seimbang bagi kehamilan dan persalinan.

3. meningkatkan upaya pemasangan poster, dan menyediakan leaflet untuk pengunjung Puskesmas.

\section{DAFTAR PUSTAKA}

Almatsier, Sunita. 2004. Prinsip Dasar Ilmu Gizi. Jakarta: PT. Gramedia Pustaka Utama.

Amargustini, Yetti. 2010. Determinan Kejadian Komplikasi Persalinan Di Indonesia, Analisis Data Sekunder SDKI 2007. Tesis, FKM Prodi Pascasarjana, UI, Jakarta.

Bagus, Manuaba Ida., Chandranita Manuaba Ida Ayu., Fajar Manuaba Ida Bagus. 2012. Buku Kebidanan, Penyakit Kandungan, dan KB. Jakarta: Penerbit Buku Kedokteran EGC.

Depkes RI. 2009. Pedoman Pemantauan Wilayah Setempat Kesehatan Ibu Dan Anak. Dirjen Bina Kesehatan Masyarakat Direktorat Bina Kesehatan Ibu. Jakarta. 2009. Pedoman Program Perencanaan Persalinan dan Pencegahan Komplikasi (P4K) Dengan Striker. Dirjen Bina Kesehatan Masyarakat Direktorat Bina Kesehatan Ibu. Jakarta.

Dinkes Prov. Lampung. 2012. Profil Program Kesehatan Ibu dan Anak Provinsi Lampung Tahun 2012. Seksi Kesga Bidang Bina Yankes. Bandar Lampung.
Untuk Masyarakat :

1. memenuhi kebutuhan zat gizi ibu selama hamil dan bersalin dengan makan makanan bergizi seimbang serta mengkonsumsi tablet tambah darah.

2. melakukan perawatan kehamilan, memeriksakan kehamilan ke petugas kesehatan.

3. melakukan persalinan yang sehat dan aman di fasilitas pelayanan kesehatan.

4. menjarangkan kehamilan berikutnya dengan MKJP.

5. mengakhiri kehamilan pada ibu yang berumur $>35$ dengan kontrasepsi tetap.

Kemenkes RI. 2013. Profil Kesehatan Indonesia 2012. Pusat Data dan Informasi Kementerian Kesehatan RI. Jakarta. 2013. Ancaman Gagalnya MDG'S Indonesia. Buletin Info Sehat Untuk Semua, Mediakom. Edisi 47, November 2013. Jakarta.

Lasmita, Nurul Huda. 2005. Hubungan Status Reproduksi, Status Kesehatan, Akses Pelayanan Kesehatan Dengan Komplikasi Obstetri Di Banda Sakti Lhokseumawe Tahun 2005. Jurnal Kesmas Vol.1, No.6, Juni 2007.

Puskesmas Tanjung Bintang. 2015. Profil Puskesmas Tanjung Bintang Kabupaten Lampung Selatan.

Prawirohardjo, Sarwono., et al. 2014. Ilmu Kebidanan. Jakarta: Yayasan Bina Pustaka Sarwono Prawirohardjo.

Supariasa, I Dewa Nyoman., Bakri Bachyar., Fajar Ibnu. 2002. Penilaian Status Gizi. Jakarta: EGC. Penerbit Buku Kedokteran. 